\title{
Histone H3 Trimethyl Lys36
}

National Cancer Institute

\section{Source}

National Cancer Institute. Histone H3 Trimethyl Lys36. NCI Thesaurus. Code C142872.

A post-translationally modified form of histone $\mathrm{H} 3$ where the lysine residue at position 36

is trimethylated. This modification may be involved in defining exon boundaries; it also

may be a marker for genes targ eted for transcriptional repression. 